\title{
"Si gran volume in piccola e manigevole forma": Bindoni and Pasini's 1535 edition of the Orlando Furioso*
}

Francesco Bindoni and Maffeo Pasini operated one of the largest publishing houses in Venice during the first half of the sixteenth century. ${ }^{1}$ The partners specialized in popular genres such as chivalric literature, and between 1525 and 1542 they produced eight editions of Ariosto's Orlando Furioso, a title that enjoyed wide success on the book market. ${ }^{2}$ The most important of these editions, and one which holds a prominent place in the publishing history of the Furioso in the Cinquecento, was the octavo they issued in 1535, the first edition in which the text of the poem was printed with a set of paratexts. ${ }^{3}$ Lodovico Dolce, the editor of the book, prepared two dedicatory letters, an "Apologia" in which he defends Ariosto from detractors, and three other paratexts designed to assist the readers: a glossary in which he explains some difficult words found in the Furioso; a list of the additions Ariosto made in the final version of the poem; and a table of characters listing their appearance in major episodes. This was the first time that the Furioso was given a paratextual apparatus, and it marked the beginning of a much-imitated editorial practice; over the course of the sixteenth century this practice would eventually see the text submerged by notes in the margins, by commentary preceding and following each canto, and by extensive critical material before and after the poem. The paratexts in the Bindoni and Pasini edition are relatively brief, but they represent a significant source for the early reception of the Furioso, since they reflect and enact the well-defined marketing strategy that Bindoni and Pasini had developed in response to the book's intended public. The principal concern of this article will be to identify how the paratexts and the typographical features of the octavo reveal the readers foreseen by Dolce and the publishers and to illustrate the ways in which the book was intended to serve the strategies those readers used in approaching the $F$ urioso. ${ }^{4}$ The examination of the edition is made from the perspective of historical bibliography, and the analysis proceeds from the assumption that the material forms by which texts are reproduced and transmitted are fundamental to the study of their reception.

A brief outline on the Furioso's history in print will provide the necessary context for the discussion to follow. By the time Bindoni and Pasini published their edition in 1535, Ariosto's work had already established itself as a 'best- 
seller.' Since the appearance of the princeps in Ferrara in 1516, the work had been issued in 21 additional editions, most of which were printed in Venice, although Florence, Ferrara, and Milan each produced at least one edition. ${ }^{5}$ These were printed in accordance with one of two typographical models: quartos in roman letter, sometimes illustrated, meant for the upper, more cultivated segment of the book market that could afford this large format; and smaller octavos intended for the lower end of the market, without illustrations and usually in gothic types. ${ }^{6}$ These two models were therefore designed to respond to the demands of different readerships. On this point, the editions of the Furioso under consideration reflected basic typographical trends of the time, and a brief divergence to consider the question of the relationship between the physical features of Cinquecento books and their intended readership or buyers will illuminate fundamental aspects of the 1535 Furioso. ${ }^{7}$ Book historians generally agree on a basic typology for the early part of the sixteenth century in Italy: books in quarto were made for a cultivated class of readers that included humanists, nobles, civil servants, and members of courtly society in general, while the smaller octavos were for "popular readers," those "ordinary readers of little learning and lower social status" (Grendler 453). ${ }^{8}$ This dichotomy hinges on a structural fact with fundamental implications for the cost of books: an octavo gathering contains twice as many leaves as a quarto gathering folded from the same sheet, which means that a text printed in octavo and with the use of a smaller typeface requires half as much paper to produce as the same text printed in the larger format; the consequent saving reduces the cost of individual copies, placing them within the reach of less affluent readers. The differences in format also involved other important divergences: quartos tended to be printed in roman, a style of typeface deriv'd from humanist script, and octavos in gothic, considered by printers in Italy to be cruder ${ }^{9}$ quartos tended to be used for texts in either Latin or Italian, but octavos only for those in the vernacular; the larger format carried classical texts, but also contemporary literary works, while the smaller one was used almost exclusively for books of piety and other genres that were "within the intellectual grasp" of popular readers (Grendler 453). This typology, which held true well into the 1540s, was not absolute. ${ }^{10}$ Chivalric literature, for example, was a favourite genre of both general classes of reader, enjoying the favour of both "il pubblico della corte" and "il pubblico della piazza" (Beer 245). Its wide circulation did not, however, affect the basic typographic pattern just described - the aristocratic public read it in quarto volumes in roman letter, popular readers used octavos in gothic. ${ }^{11}$

Bindoni and Pasini published four editions of the Furioso before 1535: in octavo in 1525,1530 , and 1533 , and in quarto in $1531 . .^{12}$ Since the partners followed the conventions outlined above, these editions did not present major innovations in the typographic form of the Furioso. ${ }^{13}$ In 1535 , however, they enacted a fundamental change in the presentation of the poem. This change did 
not involve any of the major physical features of the book: the text of the poem is set in the usual typeface employed for octavo editions, gothic, and in the typical layout of two columns of five stanzas each. As in previous editions in this format, there are no illustrations to the cantos, but a woodcut showing a hand with scissors above two serpents appears on the title-page, and a woodcut portrait of Ariosto is found at the end of the book. Both were copies of blocks first used in the definitive Furioso printed by Francesco Rosso in Ferrara in 1532, and other editions of the poem with their own copies of these blocks had already appeared. Bindoni and Pasini themselves had used still another portrait cut in their 1531 and 1533 editions. ${ }^{14}$ The innovation consisted instead in the addition of a series of paratexts designed to assist the readers of the poem. ${ }^{15}$ In essence, the partners had taken the typographical model designed for the popular market and added a paratextual apparatus. Supplementary material designed to aid readers had long been a feature of editions of classical texts, and more recently it had been used in editions of vernacular works such as those of Dante, Petrarch, and Boccaccio, but this was its first appearance with the Furioso. ${ }^{16}$

Bindoni and Pasini's motivation was commercial, and it reflected changes in the book market. As Brian Richardson explains in Print Culture in Renaissance Italy, the constant increase in book production during the 1530 s resulted in greater competition among Italian publishers, especially those who served the "less experienced readers" (91) who bought editions of vernacular texts. With the rise of literacy, these readers were growing in numbers, and their needs and expectations, in particular those of the "younger and female readers and the less well educated" (91), were not being sufficiently met by the books produced at the time. In an attempt to attract this growing sector of the market, editors were hired to provide paratextual material designed to assist readers in reading and interpreting the texts they bought. ${ }^{17}$

For their 1535 edition of the Furioso, Bindoni and Pasini turned to Lodovico Dolce, a poligrafo whose long and prolific career as an editor, translator, and printing-house consultant in the Venetian publishing world is a testament to his ability to respond to the needs of Cinquecento readers. ${ }^{18}$ Dolce revised the text for publication, and he prepared the set of paratexts. ${ }^{19}$ That the objective of these labours was to create a more attractive and competitive product is evident from the title-page. It announces that this $F$ urioso is "NOVISSIMAMENTE STAMPATO E CORRETTO" and that it includes "LA GIUNTA" (i.e., the additions that Ariosto made in the third and final version printed in 1532), and it goes on to list "Una Apologia di M. Lodovico Dolcio contra ai detrattori dell'Autore, \& un modo brevissimo di trovar le cose aggiunte; e TAVOLA di tutto quello, ch'è contenuto nel Libro. Aggiuntovi una breve espositione dei luoghi difficili." ${ }^{20}$ Formulaic claims regarding the quality of the text, the newness of the edition, the presence of giunte, and the inclusion 
of supplementary material were commonly made by publishers of the period in order to differentiate a book from its competitors on the market. ${ }^{21}$ Bindoni and Pasini made sure to advertise these very features of their edition on the titlepage, the part of the book first seen by potential buyers and hence the best suited for promotional purposes. The privileged position of the title-page also renders it instrumental in establishing the typographical identity of the book, and here too the partners proved efficient. The legibility and clarity of the relatively lengthy title-page text is ensured by setting it in two sizes of roman capital letters and a smaller italic font, and by organizing it around the central woodcut illustration showing the serpents device. This balanced layout also gives further emphasis to the illustration, which already constitutes the visual center of gravity on the page. In this way, the title-page gives a distinctive and bold 'face' to the book, setting it apart from other titles in a bookshop and drawing to it the customer's eye. The title-page was a crucial instrument in the marketing of a book, and the most immediate expression of the publishers' strategy vis-à-vis the buyers they foresaw. This one reveals that Bindoni and Pasini had a clear understanding of their Furioso's intended market and of the ways to tailor the typographical presentation and textual content of their product to respond to that market's tastes and expectations.

Their calculated strategy is evident throughout the paratextual material their editor prepared. On the verso of the title-page is printed the letter to the book's dedicatee, Gasparo Spinelli, Dolce's cousin and gran cancelliere of the Kingdom of Cyprus. Here. Dolce heaps praise on Ariosto, the Furioso, himself, and Spinelli:

Ma tra quei pochi; che in questa nostra età hanro con ragione vendicato il nome di Poeta nella volgar lingua, hoggi di in gran pregio havuta; il nobile \& eccellentissimo Messer Lodovico Ariosto non è da esser riputato l'ultimo; anzi tra quanti di Ottave Rime hanno lassato alcun Poema (e forse che lascieranno) senza alcun dubbio il primo. Essendosi adunque hora il suo leggiadrissimo Furioso per opera del Pasini impresso, piu corretto; s'io non mi inganno, di quanti hoggi vanno a torno, e piu commodo anchora, (nel quale io per l'affettione, che meritamente portai sempre al suo Autore, non piccola fatica ho usato) parvemi etiandio che non poca parte d'ornamento se gli potesse accrescere; quando egli sotto il gentile nome vostro uscisse fuori. (1. Alv)

In claiming that this Furioso is "more correct" and "easier to use" than other editions, Dolce is not only extolling the distinctive features of the octavo, he is also drawing attention to his own role in creating those features. ${ }^{22}$

In a second letter, which immediately follows the text of the poem, Dolce praises a Venetian noble, Pietro Giustiniano, and dedicates to him the "Apologia," "che hora vi mando insieme con quel libro da voi tanto amato e tenuto caro" $(1.2 \mathrm{~h} 4 \mathrm{v})$. That the "Apologia" should be given its own dedicatory letter is indicative of the importance attached to it by the publishers and 
by the editor, who in writing it became the first commentator of the Furioso. Taking up 11 pages of close-set type, it is the longest paratext appended to the edition. It is directed against Ariosto's detractors, as its full title makes clear: "APOLOGIA DI MESSER LODOVICO DOLCIO CONTRA AI DETRATTORI DELL'ARIOSTO A GLI STUDIOSI DELLA VOLGAR POESIA." Addressing his "benigni Lettori," Dolce begins by explaining that the unjust criticisms of unspecified "maligne lingue" have moved him to take up the defence of Ariosto and the F urioso on behalf of the poet's admirers, and thus "espurgar l'Ariosto dai biasimi de gli ignoranti" (II. IIr-2Iv). He then proceeds to list the criticisms commonly moved against Ariosto - regarding his choice of title, his language and style, his imitations, and the additions he made to the last revision of the Furioso - and to refute each one in turn. ${ }^{23}$ Dolce, however, does not develop a systematic critical assessment of the Orlando Furioso, and the "Apologia" remains in essence a polemic that challenges the objections raised against Ariosto in order to praise his poem and, by implication, this particular edition. Nevertheless, it is of fundamental importance in the history of Ariostan criticism: aside from its chronological primacy as the first defence of the Furioso, it is a rare document of the critical concerns that characterized the reception of the work in its earliest phases. ${ }^{24}$

The "Apologia" is of equal importance in that it makes explicit Bindoni and Pasini's marketing plan, as is evident in several passages which deviate from Dolce's stated intent. For example, he devotes several lines to praising Ariosto's Satire and his comedies:

Ne mi pare di tacer in questo luoco l'elegantia, forza, e vivacità, che egli ha havuto piu ch'ogn'altro nel scriver Satyre in questa lingua; quanta si vede nelle cinque (che tante apunto ne sono) dopo la sua morte uscite in luce; \& oltre a cio non è da trapassar tacendo il verso da lui imaginato \& appropriato alla Volgar Comedia, quale nel suo Negromante e l'altre appresso si conosce, che tosto verranno fuori [...]. (1. 2I6r)

Indeed, Bindoni and Pasini printed two editions of the Negromante in March of 1535, and an edition of the Lena in May, all edited by Dolce. In the same year, the partners also printed the Satire. ${ }^{25}$ The Furioso, therefore, was the first and central element of an editorial program designed to exploit the popular demand for Ariosto's works by providing a full range of his works in affordable editions - all but one of the books cited are in the smaller and cheaper octavo format. In keeping with this program, Dolce uses his "Apologia," ostensibly a critical defence of the Furioso, as a vehicle to advertise the other Ariosto titles in Bindoni and Pasini's catalogue, titles which would have likely appealed to readers of the poem. The programmatic unity of this undertaking is apparent in the dedication of La Lena, addressed to Pietro Aretino, where Dolce speaks of the "pietosa fatica mia di haver dato in publico [...] a questi giorni correttamente \& in bella forma sotto il nome vostro, il Negromante" (1. A lv). He also 
attacks an unspecified edition of La.Lena which has been printed "in modo guasta e lacerata, che ella in se non ritiene apena altro di buono e di regolato che il nome" (l. Alv); its text is replete with errors, but his own edition is "non senza qualche mia fatica da infiniti errori espurgata" (1. A2r). The editor, therefore, promotes the comedies using the same technique that he employs in the first dedicatory letter of the Furioso - decrying the textual shortcomings of other editions on the market and stressing the correctness of his own.

In another digression, this one taking up almost a full page of the "Apologia," Dolce weaves an extended tribute to the poetic virtues of Aretino, mentioning several of his friend's works about to be printed or already out. For example:

Nel tarderanno punto le molte occupationi; che di continuo gli sopragiungono, nello scrivere a diversi Principi, che l'honorano; che fra pochi giorni, (com'io spero) non mandi fuori il suo gran Volume hoggi col titolo d'Angelica [...]. Ma di quanto egli sia nella prosa mirabile non meno, che nel verso; fino a qui pienissimo argumento fanno le due Comedie, non molti di sono uscite in luce [...] (1l. 2I4r-2I4v $)^{26}$

This passage echoes the second part of the dedicatory letter included in both editions of $I l$ Negromante, which praises Aretino and some of the same works in similar laudatory tones (1. A2r). ${ }^{27}$ None of the titles mentioned in any of these instances seems to have been published by Bindoni and Pasini, so it is fair to consider the reasons behind the publicity the partners afforded an author not on their catalogue. ${ }^{28}$ It is likely that Dolce's friendship with Aretino was a factor, and that he would be naturally motivated to advertise the latter's books. ${ }^{29}$ It is even more probable, given the close attention they evidently devoted to this edition and the control they would have consequently exerted on their editor, that the publishers sought to draw attention to their product by including florid references to a famous author who enjoyed great success with the reading public. Dolce, in what is a relatively brief text in which he endeavoured to limit his comments "per non accrescer il Libro" (1.2I1v), consequently devotes considerable attention to matters extraneous to his stated intent but instrumental to the publishers' interests.

The edition's intended readers are identified in explicit terms. Near the end of the "Apologia," Dolce, having listed some of the paratexts that Pasini included in the edition, describes the "Dechiaratione di alcuni vocaboli e luoghi difficili dell'opera," printed on $11.2 \mathrm{I} 6 \mathrm{v}-2 \mathrm{I} 7 \mathrm{v}$ :

Appresso a questo ha voluto aggiungere la dechiaratione d'alcuni vocaboli, che nel volume si trovano, al quanto oscuri per non esser accettati dall'uso commune, se non di raro, e dilucidar anchora la sententia di alcune comparationi esponendo l' historie in quelle con circonlocutioni comprese: non per altro che per servir al commodo del 
lettore non molto esercitato nella lingua: e di quelli; che non hanno cognitione delle latine lettere [...]. (1. 216r)

Dolce prepared this brief glossary of obscure words with the clear intention of helping "the reader who was inexperienced in the literary vernacular and those ignorant of Latin literature." ${ }^{30}$ The ideal readers of this edition, therefore, were those who had been swelling the ranks of the reading public in the 1530 s, the very readers who constituted the core of Bindoni and Pasini's customer base. Aware of their cultural level, the publishers and their editor responded with tools designed to meet their needs, a response which was typical and which explains the success of the firm.

As mentioned above, at the end of the "Apologia" Dolce commends Pasini, whose diligence has resulted in an edition with several useful features: ${ }^{31}$

In questo mezzo mi parrebbe che si devesse ascrivermi a vitio; se io non vi commendasse la diligentia del Pasini vostro: il quale oltra che vi porge si gran volume in piccola e manigevole forma, e correttissimo per quanto hora ha potuto; s'è ingegnato etiandio non senza molta sua fatica a sodisfatione vostra di darvi a conoscer con maravigliosa facilita tutto quello, ch'è stato dall'Ariosto aggiunto: \& oltre a cio qualunque novella o historia si contiene nel libro per tutto il continuar di quelle con una brieve e facilissima tavola: per modo che ciascuno potra legger quello, che piu gli piacera senza fatica di travolger tutta l'opera. (1. 216r)

These comments, in addition to promoting the paratexts that follow the "Apologia," illustrate the interdependence that exists between the textual, paratextual, and material aspects of the edition. First, Dolce identifies the advantages of the book's format, which allows Pasini to offer a lengthy text in a small and easily handled size ("si gran volume in piccola e manigevole forma"). When he refers to the "Breve modo di trovar tutti i luoghi dall' Autore aggiunti," a list of the additions Ariosto made in the final version of the poem, he emphasizes the "marvelous ease" with which these can now be found..$^{32}$ Finally, he mentions the last paratext appended to the edition, the "Tavola delle Historie e Novelle contenute di tutta l'Opera," which is a table of characters listing their appearance in major episodes and novelle. ${ }^{33}$ Dolce stresses that this "brieve e facilissima tavola" allows one to find favourite passages without "la fatica di travolger tutta l'opera." The importance of these two indices is such that the points Dolce makes in the "Apologia" warrant reiteration. In the brief note titled "Mapheo Pasini alli Lettori" and placed immediately before the two paratexts, the publisher writes:

Perche adunque sono alcuni; i quali si dilettano di saper le cose dall 'Ariosto aggiunte; senza fatica di legger tutto il libro: \& appresso estimando di molto piacere ai leggenti il poter con facilità trovar quello, che loro piu aggrada di legger: habbiam notato qui di 
sotto l'ordine da per se chiaro, e la Tavola; per i quali duoi modi ciascuno potra servendosi a suo piacere fuggir il fastidio e la fatica di volger piu carte. (2I8r)

Pasini and Dolce foreground the material difficulties inherent in handling a book with a text as lengthy as that of the Furioso in order to advertise the practical advantages offered by the smaller octavo format and by the paratexts. In Pasini's description of these paratexts - i.e., they allow readers to locate the passages they want to read "without the toil of reading the entire book" and to avoid "the bother and trouble of turning many pages" - there is also an implicit recognition of the further challenges posed by the narrative complexities of the Furioso: readers require assistance not simply to find specific passages, but also to follow individual narrative threads in the highly discontinuous poem.

The list of additions and the "Tavola" are not the only means by which the publisher and his editor have responded to this perceived need. The two paratexts are not simple lists of leaf references: as is explained clearly in their titles, each one of these references is keyed to the text of the Furioso by a marginal note printed beside the relevant passage. ${ }^{34}$ These marginal notations represent a significant moment in the evolution of the Furioso's typographical form, for this is the first time that the text shares the page with extratextual matter. More importantly, the notations and the two indices constitute a reference system that enables readers to pinpoint passages quickly and easily. The different elements of the edition, therefore, are not disparate parts, but they function together as a carefuily conceived whole. The publishers were following a common promotional practice when they advertised the paratexts prominently on the title-page, in the "Apologia," and in the note to the reader, but it is also likely that they intended to make certain that the value of these features was communicated to potential buyers.

The particular integration of text and paratext engineered by Dolce and the publishers was meant to serve the various strategies that they envisioned would be deployed to read the Furioso. Since their presentation of the work was successful and often copied (as will be seen below), this edition not only reflects their preconceptions, but it also reveals basic evidence of the ways in which the poem was actually read. The comment that readers will use the "Tavola" to find "quello, che loro piu aggrada di legger" (1.2I8r) indicates that the Furioso was already familiar to them, either through personal reading or by having heard it read aloud; it also suggests that the text, or more specifically, favourite passages within it were the object of repeated readings. The list of additions would have attracted those who knew the Furioso in an earlier version and wanted to read only the new material. It would also have been useful as a reference tool to those interested in comparing the different versions - poets, perhaps, or scholars. But it is the system of cross-referencing created by the "Tavola" and the marginal notations that represents the best evidence of the reading practices applied to the Furioso in the 1530s. In the "Apologia," Dolce writes that Pasini 
took great pains "a sodisfatione vostra di darvi a conoscer con maravigliosa facilita [...] qualunque novella o historia si contiene nel libro per tutto il continuar di quelle con una brieve e facilissima tavola" (1. 2I6r). In the title of the "Tavola," he notes that the leaf references listed therein "dimostrano con facilità il principiar e continuar di quelle [historie e novelle]. e pongasi mente, che sempre trovarassi posto in margine il nome di quello, che si vorrà leggere" (l. $218 v$ ). In other words, these paratexts can help to overcome the discontinuity created by Ariosto's frequent narrative breaks and constant shifts between multiple plot lines: readers can use them to piece together and follow a single narrative line. and thus read it as a discrete unit, independently of the rest of the text. It is precisely the reader who engages in this kind of personalized, selective, and non-consecutive reading of the Furioso who encounters "fastidio" and "fatica" in turning over the pages of the whole book, a problem that a reader who follows an orderly, linear progress through the text does not experience despite the book's bulk.

As is evident, Dolce had understood the implications for readers of a fundamental and problematic characteristic of the text. In later decades, critics sought to justify and seek solutions to the Furioso's lack of continuity on theoretical grounds, or they used it to attack the poem. The publishers and their editor here moved to remedy it with their indices and marginal notations - a bibliographical solution involving the paratexts and typographical elements such as the layout (i.e., the use of the margins). It is true that their motivation was primarily commercial, and that their intention was to make a product that readers would purchase, but it is also apparent that their understanding, or at least Dolce's, of their readers' habits was rather sophisticated. The paratexts, and their integration with the text, were founded upon a clear awareness of the various reading practices they were meant to support. It is the use which readers made or wanted to make of the Furioso that governed Dolce and Pasini's decisions regarding the edition, and the paratexts were devised in order to be useful to readers. This principle of practical utility and function was a manifestation of the economic forces that shaped publishing, but it implied an understanding of the modes of reading applied to the Furioso.

Dolce's paratexts exploited the edition's fundamental physical characteristic, its size: this book was affordable, easy to handle, and it allowed the reader to navigate the text conveniently and quickly. Bindoni and Pasini, in short, were selling the practical advantages of the Renaissance equivalent of the modern paperback to a specific sector of the book-buying public, the readers who had bought the Furioso in the octavo format since the 1520 s. Their product was innovative; it possessed a distinct advantage over its competitors on the market, and it was commercially successful. This edition introduced a formula for printing the Furioso in octavo that was copied by all successive editions in this format for several years. Between 1535 and the appearance of the first Furioso by the Venetian publisher Gabriele Giolito, seven other octavo editions of the 
poem were published. ${ }^{35}$ All followed the basic typographical model - gothic letter for the main text and paratexts to assist readers - established by Bindoni and Pasini in 1535. There are some divergences, which is inevitable considering the number of printers involved: in some editions, the serpents device on the title-page is replaced by the portrait of Ariosto, in all probability because the printer lacked a copy of the device; some editions lack a number of the Bindoni and Pasini paratexts, or place them in a different order, or add different ones. ${ }^{36}$ These departures, however, do not alter the basic formula established in 1535 , and its repeated appearance bears witness to the satisfaction of readers. The success of the Bindoni and Pasini formula lasted until Giolito introduced new models for the typographic presentation of the Furioso with the quarto and the octavo he published in 1542 and 1543, respectively. Previous models were rendered obsolete by the success of these editions, and Bindoni and Pasini did not print Ariosto's text after $1542 .{ }^{37}$ One the major features of the Giolito editions was a substantial and complex paratextual apparatus prepared by the editor who was to become the publisher's major collaborator, Lodovico Dolce.

The Bindoni and Pasini edition illustrates the significant role played by publishers and editors in the diffusion and reception of literary texts in sixteenthcentury Italy. Bindoni and Pasini chose a specific market for their Furioso, and then, with the assistance of Dolce, they ascertained the cultural preparation and reading habits of the buyers they had targeted. These factors guided them in choosing the typographic characteristics and presentation of the edition, and in determining the structure and content of the paratexts. The book is both the result and the expression of their intentions, and by examining it as a material artefact, as a bibliographical fact, those intentions can in large part be recovered. Bindoni and Pasini operated in the highly competitive world of the Venetian publishing industry; hence they were motivated primarily by the economic imperatives basic to producing a commodity that consumers would purchase. But if a book is a commodity, it is also a text, and its buyers are also readers. The partners needed to consider and to respond to the textual nature of their product and to tailor it to meet the needs of their readers, but the book itself, once produced, affected the ways in which these readers responded to the text. As a consequence, the octavo partakes of the dynamic fundamental to the nature of all books: a book is shaped by its intended readership and yet it conditions actual reading. Publishers and editors, therefore, enact a complex mediation between text and reader, and this mediating function is embodied in the material object they produce. ${ }^{38}$ The importance of this particular mediation of the Furioso lies in the fact that it gained wide currency. The response of Dolce and the publishers to the perceived demands and tastes of their intended readership proved to be successful, and the innovative presentation of the Furioso they designed was much imitated in the $1530 \mathrm{~s}$. We can be certain, therefore, that these books and their paratexts were in fact used to read the Furioso, and that they effectively conditioned its reception. By studying them as biblio- 
graphical artefacts, we can arrive at a more historically accurate understanding of the interpretations of Ariosto's text during this period, and we can gain a more detailed sense of general reading practices in the Cinquecento.

University of Toronto

\section{APPENDIX: BIBLIOGRAPHICAL DESCRIPTION OF THE EDITION}

In the transcriptions, underlining indicates text set in gothic types. Transcriptions are in quasi-facsimile: characters are shown as they occur on the printed page, and words and punctuation marks printed together without spaces are not separated. A bar used over vowels to indicate an abbreviation has been rendered here as an umlaut (i.e., ä, ë, ö). Abbreviation symbols are shown in their actual form, i.e. ? for "con," and Z for the ampersand. The various forms of the long s, some with a descender and others without one, are all given with descenders.

Ludovico Ariosto, Orlando Furioso. Venezia, Francesco Bindoni e Maffeo Pasini. 1535.

Title-page. ORLANDO FVRIOSO I DI MESSER LVDOVICO ARIOSTO I CON LA GIVNTA, NOVISSI= | MAMENTE STAMPATO I E CORRETTO. | [a woodcut serpents device, $70 \times 52 \mathrm{~mm}$, and on its left and right sides the motto 'DILEXISTI MALITIAM I SVPER BENIGNITATEM.'] I CON Vna Apologia di M . Lodouico Dolcio contra ail detrattori dell' Autore, \& vn modo breuiffimo di tro I uar le cole aggiunte; e TAVOLA di tutto I quello,ch'è contenuto nel Libro. Aggiuntoui I vna breue efpofitione dei luoghi difficili.

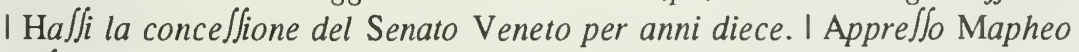
Pafini. I [rule: $25 \mathrm{~mm}$ ] I M D XXXV.

Colophon. Imprello in Vinegia apprello di Mapheo Palini, I T Francelco di Alellandro Bindoni, compagni. I Negli anni del Signore. M . D . X X X V .

$8^{\circ}: A-2 G^{8} 2 H^{4} 2 I^{8} 2 K^{4} .256$ ll., ff. [1] 2-244 [12]. \$4 (-Al).

\section{CONTENTS}

[A1r] Title-page.

[Alv] Dedicatory letter: 'AL MAGNIFICO ET ECCELLENTE M. I GASPARO SPINELLI, GRAN CAN I CELLIERE DEL REGNO DI CI I PRI 


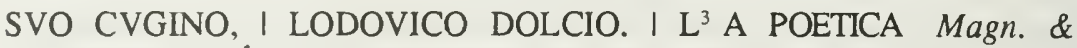
eccellente.M.GaJparo [...]'.

[A2r] Head-title: 'ORLANDO FVRIOSO DI MESSER LVDO I VICO ARIOSTO NOBILE FERRARESE ALLO I ILLVSTRISSIMO E REVERENDISSIMO CAR I DINALE DONNO HIPPOLYTO DA I ESTE SVO SIGNORE. I CANTO PRIMO. I L ${ }^{2}$ E döne, icauallier [... 2 coll. x 4 stanzas]'.

[A2r-2H4r] OF text. 46 cantos.

[2H4r] End of OF: '[2 coll. $x$ 2 stanzas] I IL FINE. I PRO BONO MALVM.' [2H4v] Dedicatory letter: 'AL MAGNIFICO E NOBILISSIMO MES= I SER Pietro Giuftiniano Gentilhuomo Venitiano I LODOVICO DOLCIO.

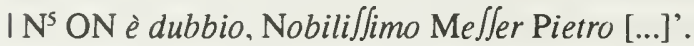

[2I1r-2I6r] Dolce's "Apologia”: "APOLOGIA DI M. LODOVICO DOL I CIO CONTRA AI DETRATTO= I RI DELL'ARIOSTO A GLI I STVDIOSI DELLA VOL I GAR POESIA. I i i $^{5}$ penlaua benigni Lettori [...]'.

[2I6v-2I7v] Glossary of difficult terms: 'Dechiaratione di alcuni vocaboli e I

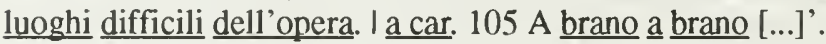

[218r] Pasini's note to the readers/List of aggiunte: 'Mapheo Pa $\underline{\text { lini alli Lettori }}$ $\mathrm{A}^{3}$ Lcune altre cole [....] II Breue modo di trouar tutti $\underline{\mathrm{i}}$ luoghi dall' Autore aggiunti I per annotatione di numero, di Cäti,e di carte. E lempre I doue lara $\underline{\text { aggiüto,troueralle notato in margine }}$ № I $\underline{\text { uo, }}$, $\underline{\text { tinuera detta aggiunta fin al }}$ loco, doue i I trouera notato fuora in margine, Vecchio. I Nel Canto nono a carte. 34. Incomincia la prima giunta: e legue fin nel decimo a carte.41 [...]'. [218v-2K1v] Table of characters and episodes: "Tauola delle Hiltorie e Nouelle contenute di tutta l'Opera per I ordine di alphabeto Z per annotatione di numeri di car I te:iquali numeri dimoltrano con facilita il princi- I piar e continuar di quelle. e pongali mente, I che lempre trouaralli polto in mar I gine il nome di quello, che I [i vorr deggere. I A I Angelica a carte 2. 3.31 [...] | [at the foot of $2 \mathrm{~K} 1 \mathrm{v}$ ] IL FINE.'

[2K2r] Colophon/Register: '[colophon] I REGISTRO. I A B C [...] S T V IX Y Z AA BB [ ... ] II KK. I Tutti lono quaderni eccetto HH e KK. che lono duerni. I [device of the Bindoni and Pasini firm, showing Tobias and the archangel Raphael, 50 × 38 mm; see Zappella 1.57 and 2, fig. 91]'.

[2K2v] Woodcut portrait of Ariosto, $98 \times 74 \mathrm{~mm}$.

[2K3, 2K4] Blank.

\section{TYPOGRAPHY}

Twenty-line measurement of gothic font used for Furioso text: G60. Type-page: 128 (134) × 89 (95) mm (D2r), 2 coll. x 5 stanzas. Catchwords: on leaf 8. Running Title: [verso] CANTO I PRIMO - XLVI. ET VLTIMO [recto] (A2v $2 \mathrm{H} 4 \mathrm{r}$ ). The italic font used to print the two dedicatory letters on $\mathrm{Al} \mathrm{v}$ and $2 \mathrm{H} 4 \mathrm{v}$ lacks its own set of capitals; roman capitals are used instead. In the Furioso 
text, roman caps are often used in place of gothic caps, which were evidently in short supply; the gothic font also lacks accented sorts, and the printers often resorted to the italic letters $o$ and $e$ to remedy this deficiency. The type initials at the head of the cantos have an average height of $5 \mathrm{~mm}$. Twenty-line measurements: I59 (dedicatory letters on A Iv and 2H4v); G60 ("Apologia"); this same gothic font is used to print the Furioso, the other paratexts at the end of the book, the catchwords, and the signatures of all gatherings except $2 \mathrm{~K}$, where roman capitals are used.

\section{NOTES}

1. Leaf Height. $157 \mathrm{~mm}$ (Bibl. Nazionale Centrale, Firenze/Nencini F.5.4.20, 1. P1); 150 mm (Bibl. Nazionale Centrale, Firenze/24.10.357, 1. P2); 147 mm (Bibl. Comunale Ariostea/S.19.6, 1. A4).

2. Fingerprint. o.co e.e; e;ra egep (3) 1535 (R).

3. Woodcuts. Reproductions of the serpents device and the portrait of Ariosto are found in Essling (2.2: 495). On the portrait block, see Mortimer 1.34-35, and Muraro and Rosand 117, fig. 91. Both provide reproductions of the portrait, and Mortimer also includes one of the device, but these are taken from editions of Ariosto's comedies printed by Bindoni and Pasini in 1535. The same blocks were used again for Bindoni and Pasini's 1540 octavo edition of the Furioso (see n. 35 in the main article; in that edition, the device appears on the title-page, and the portrait on $1.2 \mathrm{~K} 2 \mathrm{v}$ ). The serpents device on the title-page is based on the original woodcut used in the 1532 edition printed in Ferrara by Francesco Rossi, where it is found on 1. h8r; in this edition, the motto has been moved outside the woodcut itself, and the block is a mirror image of the original, a distiguishing trait of blocks which are modelled not on another woodcut, but on the impression it makes on the printed page. Traditionally believed to be Ariosto's answer to his detractors, the block of the 1532 impresa was in fact the property of the printer, although the author may have had a hand in creating it (Fahy 111-12). On the biblical sources of the motto "dilexisti malitiam super benignitatem," see Casadei 150-51, which stresses that both this and the "pro bono malum" motto (which in this edition appears on 1. $2 \mathrm{H} 4 \mathrm{r}$ ) express the theme of human ingratitude; he also cites the more recent critical studies devoted to the interpretation of the various devices in early editions of the Furioso. The portrait of Ariosto on $1.2 \mathrm{~K} 2 \mathrm{v}$ is a close copy of the original that appeared on $1 . \mathrm{h} 7 \mathrm{r}$ of the Rossi edition, the design of which is attributed to Titian. For a discussion of the cuts in the 1532 edition. and the question of their attribution and ownership, see Fahy, L'Orlando 16 and 109-12 (he lists extant copies of this edition on 15-31, and reproduces the portrait and the serpents device as Tavv. II and III, respectively); on the portrait alone, see Muraro and Rosand 116-17 and fig. 90. 
4.Privileges. The question of the status of this and the other editions published after Ariosto's death vis-à-vis the privileges that he had obtained, and that his heirs sought to have transferred to themselves, is still unresolved. The import of the declaration "Hassi la concessione del Senato Veneto per anni diece" on the title-page is, therefore, not clear. In discussing this edition and this declaration, Fahy states: "edizione autorizzata, quindi, e perciò, si è tentati di supporre, anche approvata dagli eredi, ma gli stampatori erano gli stessi Mafeo Pasini e Francesco Bindoni che, nel 1533, avevano approfittato della morte del poeta per far stampare un'edizione certamente non approvata [....] poi si succedettero a Venezia nel 1535 e nei due anni successivi ben sei altre edizioni, che è difficile credere fossero tutte approvate dagli eredi" (106). On the question of privileges, see Fahy 102-107, and the bibliographical references given therein; see also Trovato 68 and 97.

5. Dating. This edition, dated simply 1535 , was probably printed during or before the month of March - see note 24 in the main article.

\section{REFERENCES}

Agnelli-Ravegnani 41-42; Brunet 1.429; EDIT16 n. 2548; Essling n. 2257; Graesse 1.197; Guidi 25-26; Melzi/Tosi 1838, 122-23; Melzi/Tosi 1865, 4041; Mortimer n. 27; Muraro 117, fig. 91; Sander 1.97.

\section{COPIES EXAMINED}

Florence, Bibl. Nazionale Centrale (Nencini F.5.4.20, lacking 11. A1, 2K3 and 2K4; 24.10.357, lacking 1. 113); Ferrara, Bibl. Comunale Ariostea (S.19.6).

\section{OTHER COPIES}

Vatican City, Bibl. Apostolica Vaticana (Ferraioli V.5467, $16 \mathrm{~cm}$ ); Naples, Bibl. Universitaria; Vicenza, Bibl. Civica Bertoliana; Vienna, Österreichische Nationalbibliothek (*35.H.156).

\section{NOTES}

* Research on the sixteenth-century editions of the Furioso studied in this article was carried out with the support of a Doctoral Fellowship from the Social Sciences and Humanities Research Council of Canada.

The following abbreviations have been employed: l.=leaf, ll=leaves, $r=$ recto, $v=v e r s o$, $\mathrm{n} .=$ number., $\mathrm{ns} .=$ numbers. 
1 On Bindoni and Pasini, who were in effect printer-publishers, see Menis; Ascarelli and Menato 349-50, 360-61; Harris, Bibliografia 2.93-94; and Harris, "L'avventura editoriale" 95 96, which includes a list of chivalric titles they published. The partnership was active from 1524 to 1551 , and it produced, according to Menis, over 360 editions. Francesco Bindoni was Pasini's step-son: after the death of his father, Alessandro, circa 1522-23, Pasini married the widow. Menis suggests that Pasini was the senior parner, which might explain why only his name appears on the title-page and in the heading of the note to the readers in the 1535 Furioso (1. $218 \mathrm{r}$ ).

2 For a general overview of the publishing success enjoyed by the Orlando Furioso in the sixteenth century, see Javitch 10-14, and, although dated, Fumagalli 17-56. Over the course of the century, 154 editions of Ariosto's work were printed: this figure refers to the total number of full-text editions in Italian, and it was calculated by Servello using the data in the second edition of volume 1 of EDIT16, a recent and reliable union catalogue of several hundred Italian libraries. Servello also provides useful tables and graphs illustrating the chronological and geographic distribution of Furioso editions to 1600 (17-19). A more detailed statistical survey of these editions is provided by Pace, but her analysis is founded on a considerably less valid empirical base than Servello's, namely the Annali of Agnelli and Ravegnani. Designed to provide a single descriptive listing of all editions of Ariosto's works up to the 1920s, the Annali remains the only comprehensive bibliography of the subject; it is, however, out-of-date, incomplete, methodologically deficient, and therefore fundamentally unreliable.

3 Although the term paratext is borrowed from the work of the French narratologist Gerard Genette, I use it in a restricted sense, as Javitch does, to refer to all those textual elements of an edition other than the poem itself: critical commentaries, glossaries, letters to the reader, indices, dedications, etc. For Genette's notion of the term, see Paratexts.

4 An analysis of these paratexts as they relate to the Furioso's critical reception is beyond the purpose of this article. On Dolce and his work for this edition, see notes 18 and 19 below.

5 My work on this edition is part of a larger bibliographical project on the publishing history of the Furioso in the first half of the Cinquecento. My research, in which direct examination of extant copies is used to validate and supplement the data provided by catalogues such as EDIT16, NUC, and BLC, has thus far established that 23 editions of the Furioso were printed during the period 1516-35. I have indicated below in notes 12 and 35 the location and shelf number of the copies of the Bindoni and Pasini editions I have examined. For the location of copies of the other editions, I refer the reader to the aforementioned catalogues; when any of these editions are discussed in the antcle I have, however, provided the relative EDIT16 entry number. In the following provisional short list, editions are listed chronologically, and the edition number is followed by the place of publication, the publisher/printer, the date, and the format $\left(4^{\circ}=\right.$ quarto, $8^{\circ}=$ octavo); information in square brackets is derived not from imprint or colophon, but from other evidence. I thank Prof. Randall McLeod of the University of Toronto for the generous assistance he offered by examining copies of a number of these editions held by the British Library. (1) Ferrara, Giovanni Mazzocchi, 22.IV.1516, 4\%. (2) Ferrara, Giambattista da La Pigna, 13.II.1521, $4^{\circ}$. (3) Milan, Giovanni Giacomo e fratelli da Legnano / Agostino da Vimercate, 22.IV.1524, $4^{\circ}$. (4) Venice, Nicolò Zoppino / Vincenzo Polo, 20.VIII.1524, $4^{\circ}$. (5) [Venice, Giovanni Francesco e Giovanni Antonio Rusconi], 1524, $4^{\circ}$. (6) Venice, Francesco Bindoni e Maffeo Pasini, IX.1525, $8^{\circ}$. (7) [Venice], III.1526, $4^{\circ}$. (8) Milan, Giovanni Angelo Scinzenzeler, 30.V.1526, $4^{\circ}$. (9) Venice, Sisto Libbraro, 31.VIII.1526, $8^{\circ}$. (10) Venice, Elisabetta Rusconi, 27.VI.1527, $4^{\circ}$. (11) Venice, Nicolò Garanta e Francesco da Salò / Giovanni Antonio Nicolini Da Sabbio e fratelli, 1527, $8^{\circ}$. (12) Florence, 25.VII.1528, $4^{\circ}$. (13) Venice, Giovanni Matteo Rizzo / Girolamo Pencio di Lecco, 13.111.1530, $8^{\circ}$. (14)Venice, Francesco Bindoni e Maffeo Pasini, IlI.1530, $8^{\circ}$. (15) Venice, Melchiorre Sessa, 12.IX.1530, $4^{\circ}$. (16) Venice, Nicolò Zoppino, XI.1530, $4^{\circ}$. (17) Venice, Francesco Bindoni e Maffeo Pasini, I.1531, $4^{\circ}$. (18) Ferrara, Francesco Rossi da Valenza, 1.X.1532. $4^{\circ}$. (19) Venice, Francesco Bindoni e Maffeo Pasini, VIII.1533, $8^{\circ}$. (20) Venice, Melchiorre Sessa, 10.[X.1533, $4^{\circ}$. (21) Rome, Antonio Blado, 1533, 4 $4^{\circ}$. (22) Venice, Alvise Torti, 21.III.1535, $4^{\circ}$. (23) Venice, Francesco Bindoni e Maffeo Pasini, 1535, $8^{\circ}$. 
6 Of the six octavo editions that appeared during the period in question, three were printed in gothic letter (Bindoni and Pasini. 1525; Sisto Libbraro, 1526, Bindoni and Pasini 1535), two in italic (Garanta, 1527; Bindoni and Pasini 1530), and one in roman (Rizzo, 1530). The Garanta octavo was part of that publisher's attempt to apply the Aldine model for printing the classics octavo format and italic font - to chivalric literature (see Harris, "Nicolò Garanta," esp. 106); Bindoni and Pasini, in imitating Garanta's use of italic in their 1530 edition, were probably testing the viability of the typeface on the market. Italic, however, was not successful at this point in the formal evolution of the Furioso, and it was not seen again in any format until the Gabriele Giolito quarto edition of 1542 (EDIT16, n. 2594). Evidently, the reading public was not yet ready to see Ariosto's poem presented in the same manner as the classics had been by Aldus. Similarly, Rizzo's use of roman was a premature innovation - no other octavo appeared in this font until Giolito's of 1543 (EDIT16 n. 2598).

7 The complex question of the connection between the form and function of books in the Renaissance is a common theme of the scholarship on early book history: for a summary of the subject as it pertains to Italy, see Petrucci, and Grendler, who also provides statistics on literacy; the question of readership is amply treated by Hirsch 125-53; Quondam, "La letteratura," examines these issues at several points; the basic lines of the question were drawn by Febvre and Martin (77-108).

8 The larger folio format was used to print works of law, theology, and, less frequently, literature; these volumes were usually in Latin and, for the first two subjects, in gothic letter, and they were intended mostly for scholars. The Furioso was never printed in folio during the period under consideration here.

9 There is still no comprehensive study of the printing types used in Italy during the Cinquecento. For the various styles and the terminology used to classify them, see Carter 45 91, esp. 79 and 89 for the uses of roman and gothic; see also Dowding 3-58, and Johnson; Balsamo and Tinto's study covers the development of italic; for a general survey, see Goldschmidt 1-26, and Updike 125-32, 159-63. It should be noted that the gothic faces employed in the editions of the Furioso treated here, including the 1535 octavo, are all examples of gothic rotundas, a rounder form prevalent in Italy in the sixteenth century.

10 Another important exception were Aldus' editions of the classics for the humanist market, printed in octavo with italic letter. For examples of chivalric titles in both categories, see Cutolo, Essling, and Sander.

11 For the two reading publics of chivalric literature, and the typographic typology pertinent to each, see Beer 208-10 and 235-46.

12 I have examined the following copies of these editions, listed here with their shelf numbers; 1 also list, in parentheses, other extant copies. 1525: Milan, Bibl. Nazionale Braidense, Rari Castiglioni 92 (Chantilly, Oise, Cabinet des livres, Musée Condé, III.D.59). 1530: Vatican City, Bibl. Apostolica Vaticana, Ferraioli V.5466: Cambridge, Mass., Houghton Library, Harvard Univ., *IC5.Ar434.5160.1530c (London, British Library, G. 10971; Pistoia, Bibl. Comunale Forteguerriana; Trento, Bibl. Comunale). 1531: Ferrara, Bibl. Comunale Ariostea, S.16.1.4 (London, British Library, G. 11067; Venice, Bibl. Nazionale Marciana). 1533: Ferrara, Bibl. Comunale Ariostea, S.16.1.12; Cambridge, Mass., Houghton Library, Harvard Univ., *IC5.Ar434.516o.1533 (London, British Library, G. 10972).

13 The 1525 and 1533 octavo editions were both printed in gothic, and the 1531 quarto was printed in roman. As explained above in $\mathbf{n} .6$, the 1530 edition in italic was printed in imitation of Garanta's octavo of 1527, and therefore it cannot be considered innovative. It could be argued that the 1525 octavo, which was the first Furioso printed in that format, constitutes an innovation, but this edition, an octavo in gothic types, follows a typical typographic model of the period for chivalric texts.

14 On these illustrations, see the Woodcuts section of the Appendix. Blado's 1533 Furioso uses close copies of the 1532 portrait block and serpents device (l. h7r and $\mathrm{l}$. h8r, respectively): tavola XXII in Agnelli and Ravegnani reproduces the latter block. On Blado's edition, see Fahy, L'Orlando 189-91. Another copy of the Ferrara portrait block was used by Torti on the 
title-page of his 1535 Furioso (see reproductions in Essling 2.2: 495, and Agnelli and Ravegnani, tavola XX111). It is possible that this edition, dated 21 March 1535, precedes Bindoni and Pasini's octavo, dated simply 1535, but not likely; see n. 25. An entirely different portrait of Ariosto had been used by Zoppino on the title-page of his 1530 edition (EDIT $16 \mathrm{n}$. 2529; the title-page is reproduced in Essling 2.2: 491, and in Agnelli and Ravegnani, tavola XVIII). Bindoni and Pasini used a close copy of the Zoppino block on the title-page of their $153 \mathrm{l}$ quarto and on $1.2 \mathrm{H} 4 \mathrm{v}$ of their 1533 octavo. By 1535, therefore, the practice of printing the Furioso with the author's image was common, and they were simply following an established convention. Their placement of the serpents device on the title-page was, however, unprecedented.

15 Single paratexts, all brief, had appeared in several editions published before 1535 . Bindoni and Pasini, for example, had printed a laudatory sonnet by Gian Battista Dragoncino in their 1525 and 1530 editions (1. Al in both cases), and a letter to the reader in their 1531 quarto (1. Alv). This letter was an abbreviated version of the one published in the Zoppino edition of the previous year (also on $1 . \mathrm{Alv}$ ).

16 See Richardson 28-108 for an overview of the various kinds of paratexts (commentaries, biographies, indices) included in editions of the Decameron, Canzoniere, Trionfi. Commedia, and other vemacular texts printed in Italy, particularly in Venice and Florence, from the late fifteenth century to the early 1540s. On the printing history of the Commedia and its commentaries in the Renaissance see Parker 130-51.

17 Richardson 90-91. Editors also prepared the texts for publication, carrying out corrections and revisions to render them accessible to the widest possible readership. For their aims and methods, their function in the Venetian publishing world, and their influence on reading habits, see Richardson, and specifically $90-108$ for the period 1531 to 1545 ; see also Trovato. For a more detailed discussion of the development of the publishing industry in Italy in the sixteenth century, see Santoro, Storia del libro italiano 71-136; Santoro's approach integrates economic and cultural considerations, including the growth of literacy, and he also provides statistics on total book production. Quondam, "La letteratura" covers the same issues, but from the perspective of literary history; for an overview of the effect that the rise in the numbers of readers had on the book market, see Bottasso; on the expansion of the book market in Venice, see Pesenti 93 100.

18 Dolce was active from 1532 until his death in 1568, authoring, translating or editing 358 editions (Di Filippo Bareggi 58). On Dolce, his work for Venetian publishers, and the cultural milieu in which he operated, see Terpening, Di Filippo Bareggi, esp. 58-60, and Trovato 67-71.

19 Dolce's paratexts have been given only cursory attention: see Fumagalli 25-26; Fatini 8-9: Servello 24; Trovato 29, 68, 202-203; and Richardson 95-97. On the "Apologia" alone, see Binni 11; Ramat, La critica ariostesca 14-15; Ramat, "Lodovico Ariosto" 364; Beer 209; Javitch 171-72. Terpening 27-29 discusses the "Apologia" printed in the 1540 edition by Bindoni and Pasini (see n. 35 below); the text there follows closely the 1535 original. Hempfer comments on the "Apologia" at various points, see esp. 69-70, 143-44, 277-78, and 289. Dolce's revision of the text lies outside the scope of this article; Trovato examines his general editorial practice over the course of chapters 8-11 (191-297); in discussing the 1535 Furioso, he affirms that "L'edizione [...] era davvero molto corretta, almeno sul piano ortografico" (202), and provides some examples of Dolce's revisions (222-24); see also Richardson 95-97.

20 In transcriptions, abbreviations have been expanded, words separated, and the letters $u / v$ regularized, but capitalization, accentuation, and punctuation have not been changed.

21 See Trovato 19-29 for the practice, common among fifteenth and sixteenth-century Italian publishers, of using title-pages, colophons, and dedications to promote the quality of the corrected text and the presence of giunte in their books, as well as to announce books in preparation and to make favourable comparisons between the printer's titles and those of his competitors.

22 I follow Richardson's translation of "piu commodo" in the passage cited: "In his dedication Dolce said that he had now made the Furioso 'easier to use' ("più commodo'); as he explained 
in his Apologia, he had added, at Pasini's request, notes on words which were somewhat obscure because they were only rarely accepted by common usage [...]" (96); see below for discussion of the "Dechiaratione."

23 The salient points developed by Dolce in the "Apologia" are summarized in Fatini 8-9, and Ramat, La critica ariostesca 14-15; see $n .19$ above for a list of the brief critical treatments of this text.

24 As stated above, a detailed analysis of the "Apologia" and its place in the early critical reception of the Furioso is not my purpose here, but some general comments should nevertheless be made. Javitch observes that the "one early defense of the poem that was not provoked by neoAristotelian criticism was the very first, Lodovico Dolce's "Apologia"' (171). This is not surprising since "it was not until the 1540 s that Aristotle's treatise really began to be valued and assimilated by Italian literati" (Javitch 16; on this point see also Turolla 132). Dolce does draw on Horatian poetics, and he makes several references to Horace and the Ars Poetica to lend authority to his argument: in exalting Ariosto's poetic virtues, for example, he affirms that "Egli gióva e diletta parimente" (1. 215v). It must be remembered that in 1535 Bindoni and Pasini also published Dolce's Italian translation of the Ars Poetica; on this octavo edition, see Weinberg 1.101-2 (in his bibliography Weinberg lists La Poetica D'Horatio Tradotta per Messer Lodovico Dolce. In Vinegia per Francesco Bindoni, \& Mapheo Pasini compagni. Del mese di Agosto. MDXXXV). On the reception of Horace's text and Aristotle's Poetics in the Renaissance, and on their fusion, see the first volume of Weinberg. Finally, it is worth noting that the various comparisons that Dolce draws between Ariosto and Virgil are significant in that they represent the beginning of that process of canonization, described by Javitch, which the Furioso underwent in later decades, a process founded upon the affiliation of the poem to the epics of antiquity - Dolce explicitly claims that Ariosto is "un Poeta Magnifico, colto, \& elegaute; e degno d'esser apposto all'antichita" (1. 215v); on this point, see also Richardson 95.

25 Dolce edited four editions of Ariosto's minor works for Bindoni and Pasini in 1535, which I list here with relevant data, indicating the copies I examined parenthetically:

(1) Il Negromante, 4\%; dedicatory letter, 11 . Alv-A2r: "AL DIVINO SIGNORE, MESSER PIETRO ARETINO, LODOVICO DOLCIO. Empio veramente e del mondo e di se stesso nemico [...]"; colophon, 1. I3v: "il Mese di Marzo M. D. XXXV."; (EDIT16 n. 2544; Milan, Bibl. Trivulziana, H.1254).

(2) Il Negromante, $8^{\circ}$; dedicatory letter, 11 . A2r $-\mathrm{A} 3$; , same heading and text as (1); colophon, 1. E8r: "Mazo M.D.XXXV"; (EDIT16 n. 2545; Bologna, Bibl. Comunale dell'Archiginnasio, Landoni 2139).

(3) La Lena, $8^{\circ}$ dedicatory letter, different from letter in (1) and (2), ll. A1v -A2r: "AL DIVINO SIGNORE MESSER PIETRO ARETINO LODOVICO DOLCIO. La perversa malignità d’alcuni [...]"; colophon, 1. E4r: "Il Mese di Maggio" 1535; (EDIT16 n. 2541; Ferrara, Bibl. Comunale Ariostea, S.16.2.44).

(4) Le Satire, $8^{\circ}$; title-page, 1. A1r: "Del mese di Iuglio. MDXXXV"; (EDIT16, n. 2552; Vatican City, Bibl. Apostolica Vaticana, Stamp. Ross. 6647).

If Dolce's comment in the "Apologia" regarding Ariosto's comedies is interpreted as a reference to their imminent publication by Bindoni and Pasini, then the date given in both Negromante editions, March 1535, would indicate that their Furioso, which bears only the year 1535, was published either before March, or in March but before the two editions of the comedy. On these editions of the comedies and satires, see Trovato 68 and 97.

26 The two comedies are probably Il Marescalco and Cortigiana. In addition to the Angelica, Dolce makes references to I sette salmi, La Passione di Giesù, and I tre libri de la Humanita di Christo. For the editions of these titles printed in 1534 and 1535 see EDIT16 ns. 2328-2342; see also Quondam, "Aretino."

27 The dedicatory of La Lena mentions only one of Aretino's works: "i tre libri dell'humanità di Christo usciti dalla profondità del vostro ingegno" (1. A2r).

28 Bindoni and Pasini do not figure in the list of Aretino editions compiled by Quondam ("Aretino" 222-30; see also 213-15). Quondam based his "Repertorio" on the relative entries 
in EDIT16, which he integrated with data from other catalogues and from critical editions. He emphasizes that there still exists no relıable bibliography of Aretino editions, and that his list is designed as a provisional research tool for scholars studying the complex publishing history of Aretino's works (197-98). Many of the editions in this list tack a publisher's or printer's name, which leaves open the possibility that Bindoni and Pasini might have produced a number of them: there is no evidence to support such a possibility, but if any were to surface, the reasons for Dolce's references to Aretino's works would be clearer.

29 For Dolce's relationship with Aretino, see, for example, Di Filippo Bareggi and Terpening 16 18 and 188-89.

30 The translation is Richardson's (96). His comments on this paratext are cogent: "Dolce's 'Dechiaratione' is only two and a half pages long. Its main purpose (apart from elucidating three references to classical proper names) was to give synonyms for uncommon words or phrases. But Dolce was as concemed with justifying Ariosto's usage as he was with explaining it, for with only one exception he gave quotations of the same terms in Dante, Petrarch, or Boccaccio. One can see that his purpose here was not only to assist readers but to carry on from the Apologia his defence of Ariosto as fundamentally a 'good observer' ("buono osservatore') of the rules of vemacular grammar who had nevertheless used with discretion the licence, which all poets should have, to deviate from past usage" (96). Dolce makes this last point in one of the glosses: "Strilla, invece di strida, non è appresso al cuno Autore, ma diasi alla licentia del Poeta" (1. 217r). The "Dechiaratione" is made up of twenty-five entries, each referring to the relevant passage in the Furioso by leaf (i.e., "c." for "carta"). As Richardson notes, three are glosses of classical names; two of these are cited as part of similes ("Come quel figlio di VULCAN" and "Quale il canuto EGEO," (1. 217r)), which explains Dolce's use of the term "comparationi" in the passage cited from the "Apologia" (1. 216r). The others are glosses of difficult words, for example: "c. 8 Vanni, le penne maestre, cioè l'ali. Il Petrarcha nei Triomphi. Si, ch'al suo volo l'ira adoppi i vanni”; "c. 47 Brulla, priva, ignuda. Dante nell'Infer Canto. XXXIIII. Rimanea della pelle tutta brulla" (216v).

31 As stated in n. 1 above, Pasini seems to have been the senior partner in the business, and as such he would have been directly responsible for editorial decisions regarding format and paratexts.

32 This paratext lists, in seventeen lines of type on 1. 218r, nine giunte "per annotatione di numero, di Canti, e di carte," as its title specifies. For example: "Nel Canto nono a carte. 34. Incomincia la prima giunta; e segue fin nel decimo a carte. 41. Ricomincia la seconda nel Canto undecimo a carte. 46. e continua per infino nel duodecimo a carte, 50." (1. 218 r)

33 In the "Tavola," which takes up three pages (11. 2I8v-2KIv), the characters" names are listed alphabetically, though strict alphabetical order is not respected under each letter, and the references to the Furioso are by leaf number: "Lucina Novella a carte 75. / Lidia Novella a carte 174. / Leone a carte 230. 233. 238." (1. 2K1 r)

34 The titles give specific instructions to ensure that readers know how to use the indices in combination with the marginal notations: "Tavola delle Historie e Novelle contenute di tutta l'Opera per ordine di alphabeto \& per annotatione di numeri di carte: i quali numeri dimostrano con facilita il principiar e continuar di quelle. e pongasi mente, che sempre trovarassi posto in margine il nome di quello, che si vorrà leggere" (1. 218v); "Breve modo di trovar tutti i luoghi dall'Autore aggiunti per annotatione di numero, di Canti, e di carte. E sempre dove sara aggiunto, troverasse notato in margine Novo, e continuera detta aggiunta fin al loco, dove si trovera notat o fuora in margine, Vecchio" (1. 2I8r). For example, the "Tavola"'s entry for "Rinaldo" gives leaf 2 as the first reference, and on the second leaf of the book (A2v) the character's name is printed in the left-hand margin, beside stanza 10 of canto 1 , which describes his first appearance. The use of marginal notations "si diffonderà nei libri in volgare verso la metà del secolo" (Trovato 45, n. 30 ).

35 These editions, all printed in Venice with the probable exception of the last one, are the following; the EDIT16 entry number is given in parentheses with the location and shelf number of the copy or copies I examined. (1) Alvise Torti, IX.1536 (EDIT16 n. 2559; 
Ferrara, Bibl. Comunale Ariostea, E.2.26). (2) Giovanni Giolito De' Ferrari / Agostino Bindoni, 1536 (EDIT16 n. 2558: Bologna, Bibl. Comunale dell'Archiginnasio, 10.XX.IV.36; Cambridge, Mass., Houghton Library, Harvard Univ., *IC5.Ar434.5160.1536e; Venice, Bibl. della Fondazione Cini, 0159). (3) Agostino Bindoni, 1539 (EDIT16 n. 2578; Cambridge, Mass., Houghton Library, Harvard Univ., *IC5.Ar434.5160.1539c). (4) Alvise Torti, IV.1539. (EDIT16 n. 2580; Cambridge, Mass., Houghton Library, Harvard Univ., *IC5.Ar434.5160.1539). (5) Bindoni and Pasini, 1540 (EDIT16 n. 2582; Ferrara, Bibl. Comunale Ariostea, C.3.32; Cambridge, Mass., Houghton Library, Harvard Univ., *1C5.Ar434.516o.1540. Other extant copies: London, British Library, G. 10976 and 1073.f.32; Madrid, Bibl. Palacio; Milan, Bibl. Trivulziana; Piacenza, Bibl. Comunale Passerini Landi; Pisa, Bibl. dell'Università; Reggio Emilia, Bibl. Municipale Antonio Panizzi). (6) Giovanni Antonio Volpini, VIII.1541. (EDIT16 n. 2586; Venice, Bibl. della Fondazione Cini, 0169). (7) [Roma, Antonio Blado, post-1540] (EDIT16 n. 2550; Vatican City, Bibl. Apostolica Vaticana, Ross. 67 19). This edition was first reported in the revised version of Volume 1 (A) of EDIT16, published in 1990. BAV/Ross. 6719 is the only extant copy, and it lacks both a date and a printer's name: the title-page does not include an imprint, and the colophon was either on the last leaf, which is lacking, or it was not printed at all. An attempt to identify the printer and to date the edition was made by Servello, and is reported in her article "Ancora un Orlando Furioso"; she dates the edition between 1535 and 1542, but does not propose a printer. My own examination of BAV/Ross. 6719 leads me to propose Antonio Blado as the printer, and to shift the terminus post quem for publication to 1540. This attribution and dating are based on a comparison of the paratexts in editions of the Furioso printed in the 1530 s and early 1540 s (along the lines of Servello's analysis), and a comparison of the woodcuts and types in this copy to those in Blado's 1543 quarto edition of the Furioso, a copy of which is in the same collection at the Vatican (BAV/Ross. 4629). Both the attribution and the dating remain at this point only probable, but upon further research I hope to publish conclusive findings.

36 The octavo published by Bindoni and Pasini in 1540 followed their 1535 edition very closely.

37 The 1542 quarto (EDIT16 n. 2594) and the 1543 octavo (EDIT16 n. 2598) were the first of a long series of Furioso editions printed regularly by Giolito until 1560; their formal presentation was adopted by most other printers. On Giolito see, for example, Quondam, "'Mercanzia d'onore' / 'Mercanzia d'utile'," and, specifically on his editions of the Furioso, Javitch 31-36. Bindoni and Pasini tried to compete with Giolito by printing a quarto and an octavo in 1542 , after the appearance of his edition (EDIT16 ns. 2592 and 2593). These included paratexts that were more recent than those in their 1535 octavo, but the editions themselves presented the same typographical appearance; evidently, they were not successful, for the press, though active until 1551, never printed the Furioso again; on these editions, see Richardson 97 and 217 18; Javitch 49-50.

38 For a clear and concise overview of the theoretical issues raised here about the materiality of texts in the context of historical bibliography, publishing history, and literary theory, see Parker's introduction to her chapter "Material Production and Interpretations of the Comedy" (12430); Parker focusses on the work of Christian Bec, Quondam, Donald McKenzie, and Jerome McGann.

\section{WORKS CITED}

Agnelli, Giuseppe, and Giuseppe Ravegnani. Annali delle edizioni ariostee. Bologna: Zanichelli, 1933. 2 vols.

Ascarelli, Femanda, and Marco Menato. La tipografia del '500 in Italia. Firenze: Olschki, 1989. Balsamo, Luigi, and Alberto Tinto. Origini del corsivo nella tipografia italiana del Cinquecento. Milano: 11 Polifilo, 1967.

Beer, Marina. Romanzi di cavalleria: Il 'Furioso' e il romanzo italiano del primo Cinquecento. Roma: Bulzoni, 1987. 
Binni, Walter. Storia della critica ariostesca. Lucca: Lucentia, 1951.

BLC: The British Library General Catalogue of Printed Books to 1975. London: Bingley, 1979. 87.360 vols.

Bottasso, Enzo. "Le trasformazioni del libro e dell" editoria nel Cinquecento ed i loro riflessi fuori d'Italia." La stampa in Italia nel Cinquecento. Ed. Marco Santoro. 2 vols. Roma: Bulzoni, 1992. 1.21-47.

Brunet, Jacques-Charles. Manuel du libraire et de l'amateur de livres. 5th ed. Paris: Firmin-Didot, 1860-65. 6 vols.

Carter, Harry. A View of Early Typography up to about 1600. Oxford: Oxford UP, 1969.

Casadei, Alberto. La fine degli incanti: vicende del poema epico-cavalleresco nel Rinascimento. Milano: FrancoAngeli, 1997.

Cutolo, Alessandro. I romanzi cavallereschi in prosa e in rima del Fondo Castiglioni presso la Biblioteca Braidense di Milano. Milano: Hoepli, 1954.

Di Filippo Bareggi, Claudia. Il mestiere di scrivere: lavoro intellettuale e mercato librario a Venezia nel Cinquecento. Roma: Bulzoni, 1988.

Dowding, Geoffrey. An Introduction to the History of Printing Types. An lllustrated Summary of the Main Stages in the Development of Type Design from 1440 up to the Present Day, An Aid to Type Face Identification. London: Wace \& Company, 1961.

EDIT16: Le edizioni italiane del XVI secolo: Censimento nazionale. Vol. 1 (A). 2nd ed. Roma: Istituto Centrale per il Catalogo Unico delle Biblioteche ltaliane e per le Informazioni Bibliografiche, 1990.

Essling, Victor Masséna, prince d'. Les livres à figures vénitiens de la fin du XVe siècle et du commencement du XVle. 3 vols. Florence: Olschki, 1907-14.

Fahy, Conor. $L^{\prime}<<$ Orlando Furioso $>>$ del 1532: Profilo di una edizione. Milano: Vita e Pensiero, 1989.

Fatini, Giuseppe. Bibliografia della critica ariostea, 1510-1956. Firenze: Le Monnier, 1958.

Febvre, Lucien, and Henri-Jean Martin. The Coming of the Book: The Impact of Printing, 1450 . 1800. Trans. David Gerard. London: Verso, 1990. (L'Apparition du Livre. Paris: Albin Michel, 1958).

Fumagalli, Giuseppina. La fortuna dell' Orlando Furioso in Italia nel secolo XVI. Ferrara: Zuffi, 1912.

Goldschmidt, E. P. The Printed Book of the Italian Renaissance: Three Lectures on Type, Illustration, Ornament. 2nd ed. Amsterdarn: van Heuden, 1966.

Graesse, Jean G. T. Trésor de livres rares et précieux ou nouveau dictionnaire bibliographique. Dresde: Kuntze, 1859-69. 7 vols.

Grendler, Paul. "Form and Function in Italian Renaissance Popular Books." Renaissance Quarterly 46 (1993): 451-85.

Guidi, Ulisse. Annali delle edizioni e delle versioni dell' Orlando Furioso e d' altri lavori al poema relativi. Bologna: Tipografia in via Poggiale, 1861.

Harris, Neil. Bibliografia dell' <<Orlando Innamorato >> Modena: Panini, 1988-91. 2 vols.

_. "L'avventura editoriale dell'Orlando innamorato." l libri di Orlando innamorato. Modena: Panini, 1987. 35-100.

- "Nicolò Garanta editore a Venezia 1525-1530." La Bibliofilia 97 (1995): 99-148.

Hempfer, Klaus W. Diskrepante Lektüren: Die Orlando-Furioso-Rezeption im Cinquecento. Stuttgart: Steiner, 1987.

Hirsch, Rudolf. Printing, Selling, and Reading. Wiesbaden: Harrassowitz, 1967.

Javitch, Daniel. Proclaiming a Classic: The Canonization of Orlando Furioso. Princeton, NJ: Princeton UP, 1991.

Johnson, A. F. Type Designs: Their History and Development. 3rd ed. London: Grafton, 1966.

Melzi, Gaetano, and Paolo Antonio Tosi. Bibliografia dei romanzi e poemi cavallereschi italiani. Seconda edizione corretta ed accresciuta. Milano: Tosi, 1838.

. Bibliografia dei romanzi di cavalleria in versi e in prosa italiani. Milano: Daelli, 1865.

Menis, Ilde. "Francesco Bindoni." Dizionario dei tipografi e degli editori italiani: Il Cinquecento. 
Eds. Marco Menato, Ennio Sandal, Giuseppina Zappella. Vol. 1. Milano: Editrice Bibliografica, 1997. 138-39.

Muraro, Michelangelo, and David Rosand, eds. Tiziano e la silografia veneziana del Cinquecento. Vicenza: Neri Pozza, 1976.

NUC: The National Union Catalog. Pre-1956 lmprints. London: Mansell, 1968-80. 685 vols.

Pace, Enrica. "Aspetti tipografico-editoriali di un "best seller" del secolo XVI: l'Orlando Furioso." Schifanoia 3 (1987): 103-14.

Parker, Deborah. Commentary and Ideology: Dante in the Renaissance. Durham and London: Duke UP, 1993.

Pesenti, Tiziana. "Stampatori e letterati nell'industria editoriale a Venezia e a terraferma." Storia della cultura veneta. Vol. 4, pt. 1. Vicenza: Neri Pozza, 1980. 93-129.

Petrucci, Armando. "Alle origini del libro modemo: Libri da banco, libri da bisaccia, libretti da mano." Italia medioevale e umanistica 12 (1969): 295-313.

Quondam, Amedeo. "Aretino e il libro. Un repertorio, per una bibliografia." In Pietro Aretino nel cinquecentenario della nascita: Atti del Convegno di Roma-Viterbo-Arezzo (28 settembre-1 ottobre 1992), Toronto (23-24 ottobre 1992), Los Angeles (27-29 ottobre 1992). 2 vols. Roma: Salemo, 1995. 1.197-230.

—. "La letteratura in tipografia." Letteratura italiana. Ed. Alberto Asor Rosa. Vol. 2: Produzione e consumo. Torino: Einaudi, 1983. 555-686.

—. "'Mercanzia d'onore' / 'Mercanzia d'utile': Produzione libraria e lavoro intellettuale a Venezia nel Cinquecento." Libri, editori, e pubblico nell'Europa moderna. Ed. Armando Petrucci. Bari: Laterza, 1977. 51-104.

Ramat, Raffaello. La critica ariostesca dal secolo XVI ad oggi. Firenze: La Nuova Italia, 1954. - "Lodovico Ariosto." I classici italiani nella storia della critica. Ed. Walter Binni. 2nd ed. Vol. 1. Firenze: La Nuova Italia, 1974. 359-70.

Richardson, Brian. Print Culture in Renaissance Italy: The Editor and the Vernacular Text, 1470. 1600. Cambridge: Cambridge UP, 1994.

Sander, Max. Le livre à figures italien depuis 1467 jusqu'à 1530. Essai de sa bibliographie et de son histoire. 1942. Nendeln, Liechtenstein: Kraus, 1969. 6 vols.

Santoro, Marco. Storia del libro italiano: Libro e società in Italia dal Quattrocento al Novecento. Milano: Bibliografica, 1994.

Servello, Rosaria Maria. "Ancora un Orlando Furioso." Il Corsivo: Libro antico e censimento delle edizioni italiane del XVI secolo 1 (1991): 17-40.

Terpening, Ronnie H. Lodovico Dolce, Renaissance Man of Letters. Toronto: U of Toronto P, 1997.

Trovato, Paolo. Con ogni diligenza corretto: La stampa e le revisioni editoriali dei testi letterari italiani, (1470-1570). Bologna: ll Mulino, 1991.

Turolla, Enzo. "Aristotele e le 'Poetiche' del Cinquecento." Dizionario critico della letteratura italiana. Ed. Vittore Branca. 2nd ed. 3 vols. Torino: UTET, 1986. 1.132-37.

Updike, D. B. Printing Types: Their History, Forms, and Use. 2nd ed. 2 vols. New York: Dover, 1980.

Weinberg, Bernard. A History of Literary Criticism in the Italian Renaissance. 2 vols. Chicago: U of Chicago P, 1961.

Zappella, Giuseppina. Le marche dei tipografi e degli editori italiani del Cinquecento. Repertorio di figure, simboli e soggetti e dei relativi motti. 2 vols. Milano: Bibliografica, 1986. 